\title{
Utilization Pattern of Non-Timber Forest Products (NTFPs) among the Tribal Population of Chhattisgarh, India
}

\author{
Ashish Kumar Gupta ${ }^{1 *}$, M. L. Sharma ${ }^{1}$ and Lalji Singh ${ }^{2}$ \\ ${ }^{1}$ Dept. of Agricultural Extension, ${ }^{2}$ Dept. of forestry, College of Agriculture, Indira Gandhi Krishi Vishwavidyalaya, Raipur, \\ Chhattisgarh (492 012), India
}

\author{
Corresponding Author \\ Ashish Kumar Gupta \\ e-mail: ashish.gupta714@gmail.com
}

\author{
Article History \\ Manuscript No. AR1764b \\ Received in $30^{\text {th }}$ December, 2016 \\ Received in revised form $16^{\text {th }}$ March, 2017 \\ Accepted in final form $4^{\text {th }}$ April, 2017
}

\begin{abstract}
This paper examined the utilization pattern of Non-Timber Forest Products (NTFPs) among the tribal population living in Bilaspur district of Chhattisgarh, India. The data for this study were generated from personal interviews of 135 respondents, who were randomly selected from nine villages of the Bilaspur district. The study showed that respondents were involved in collection of various NTFPs throughout the year. However, April-June month was found as the peak period for NTFPs collection by the respondents. All the respondents were engaged in mahua collection. Among the all collected NTFPs, the respondents had utilized mainly the fruit part of various NTFPs. The average quantities of various NTFPs collected by family ${ }^{-1}$ year ${ }^{-1}$ were as follows: 1483.25 stakes (bundles) of tendupatta, 144.51 kg of mahua and $79.25 \mathrm{~kg}$ of a am. The respondents consumed $70.18 \%$ of total collected quantity of kheksha followed by putu and chhatani (69.30\%) and tendu (62.49\%), whereas the respondents were selling $100 \%$ of total collected quantity of tendupatta and lakh followed by harra (97.94\%). The data also revealed that the average annual income family ${ }^{-1}$ was maximum for mahua (₹ 2176.04) followed by char beej (₹ 1928.68) and gond ( $₹$ 1888.98). The majority of respondents (94.81\%) found bad weather as a main factor affecting the availability of various NTFPs. From this study, it could be concluded that collection, consumption and selling of NTFPs played a significant role in securing the livelihoods of the tribal population in the study area.
\end{abstract}

Keywords: Utilization pattern, non-timber forest products, tribal population, livelihood

\section{Introduction}

The broad term "non-timber forest resources" (NTFR) or "Nontimber forest products" (NTFP) refers to natural resources collected from forests apart from sawn timber. Chamberlain et al. (1998) provides a definition: non-timber forest products are plants, parts of plants, fungi, and other biological materials which are harvested from within and on the edges of natural, manipulated or disturbed forests. NTFP may include fungi, moss, lichen, herbs, vines, shrubs, or trees. They are also known as Non-wood, minor, secondary, special or specialty forest products (Shiva, 1993).

Utilization of NTFPs has been contributing much to the local livelihood (Sarmah and Arunachalam, 2011) and it may contribute as much as $20-25 \%$ of income to rural people (Vedeld et al., 2007). NTFPs may provide local job opportunity to two million people every year and contribute significantly to rural economy as more than half of the products are consumed by the tribals living in and around the forest area to meet their basic needs (Rout et al., 2010). Non-timber forest products (NTFPs) act as a source of income and facilitate the subsistence living of the tribal people (Peters et al., 1989; Hegde et al., 1996).

NTFPs like fuel-wood, medicinal plants, wild edible vegetables, house building materials etc., are an integral part of day-today livelihood activities, especially for tribal people (Sarmah et al., 2006; Saha and Sundriyal, 2013). In almost all tropical countries, the collection of NTFPs is a major economic activity (Chopra, 1993; Ambrose-Oji, 2003). Similarly in India, the collection and sale of Non-timber Forest Produce is the main economic activity for the majority of the tribal population as it offers employment that provides up to $50 \%$ of income to nearly $25 \%$ of the country's rural labour force (Appasamy, 1993; Muthyalu, 2008). About $70 \%$ of the NTFP collection in India takes place in the tribal belt of the country (Mitchell et al., 2003). An estimated $80 \%$ of the population of the developing world uses NWFP (Non-Wood Forest Products) to meet some of their health and nutritional needs (FAO, 2008). Thus, the non-timber forest products play a significant role in the livelihood of forest dwellers or communities living in the vicinity of the forest, as well as people at large in the immediate surrounding areas. 
The collection of NTFPs by tribals was primarily for meeting their subsistence needs. Over time, these NTFPs acquired commercial value resulting from huge trade transactions and income levels due to rising demand. Trade in NTFPs can act as an incentive for forest conservation by providing a source of income from resources that might otherwise appear to have little financial value (Cottray et al., 2003). NTFPs provide important products for local, national and international markets. These markets are growing rapidly and steadily (Wilkinson and Elivitch, 2000).

Non timber resources have great potential for enhancing sustainable rural development and diversified economic growth, cultural endurance, and environmental health. Few NTFPs have low cash values and hence, are used for consumption, rather than for sales, whereas rest of NTFPs has highly commercial value. NTFPs are significant especially for the poor, because they are available at low cost on common property lands. They are used by people because they have less alternative access to food and income. In a country like India, which has more than half of its population in rural areas and a large tribal population reliant on forest produce for their sustenance, NTFPs play a major role (Sawhney and Engel, 2003). The value of the produce obtained from the forest in India is ₹ 1392477000000 in which NTFPs contributes $₹ 181014300000$ while the estimated value of forest produce in the Chhattisgarh state is ₹ 46269600000 , out of this total value, the estimated value of NTFPs is ₹ 62276200000 (Anonymous, 2013). So by keeping all these facts in view, an attempt had been made in this paper to find out utilization pattern of different collected NTFPs among the tribal population of Chhattisgarh. Here, utilization pattern is worked out in terms of collection, consumption and marketing pattern of various NTFPs. The findings of this study can help the policy makers to design and implement the effective programmes concerned with the development of tribal population living in the forest fringes of Chhattisgarh in general and Bilaspur district in particular.

\section{Materials and Methods}

\subsection{Research design}

In the present investigation, ex-post facto research design was employed. This design was appropriate because the phenomenon had already occurred. Ex-post-facto research is the most systematic empirical enquiry in which the researcher does not have any control over independent variables as their manifestation has already occurred or as they are inherent and not manipulatable thus, inferences about relations among variables were made without direct intervention from concomitant variation of independent and dependent variables.

\subsection{Study sites}

The present investigation was conducted in Bilaspur district of Chhattisgarh state, India during the year 2014-2015. Bilaspur district was selected purposively because the maximum tribal population residing in Chhattisgarh plains agro-climatic zone comes under this district. Out of total 7 blocks in the Bilaspur district, Pendra, Gaurela and Kota blocks were selected purposively because maximum numbers of tribes are residing in these blocks. Then three villages were selected randomly from each selected block. In this way, total 9 villages were selected in the sample.

\subsection{Selection of respondents and method of data collection}

15 NTFPs collecting tribes were selected randomly from each selected village. In this way, total 135 NTFPs collecting tribes $(9 \times 15=135)$ were considered as respondents for this study. The data were collected personally in cooperation with forest officers and other officials of the district by using pre-tested interview schedule. The collection of data was carried out between the months of December, 2014 to January, 2015.

2.4. Estimation of average quantity collected, consumed and sold

For calculating the average quantity collected of a particular NTFP in kg family $^{-1}$ year $^{-1}$, the multiplication had been made between average family members involved in day ${ }^{-1}$ collection of that particular NTFP and average number of days devoted in a year by each person in collection of the same NTFP. Then outcome of this multiplication was again multiplied with average quantity collected of that particular NTFP by person ${ }^{-1}$ day $^{-1}$. For determining the average quantity consumed of particular NTFPs in $\mathrm{kg}$ family $^{-1}$ year $^{-1}$, the average of total quantity consumed of that particular NTFP in a year by all the households who were actually involved in collection of the same NTFP was find out. While for calculating the average quantity sold of particular NTFP in kg family-1 year $^{-1}$, average quantity consumed of that particular NTFP in a year was deducted from average quantity collected of the same NTFP in the same year.

\subsection{Estimation of average annual income}

For calculating family ${ }^{-1}$ average annual income derived from the selling of a particular NTFP, the average quantity sold of that particular NTFP by each family was calculated with the average price of the same NTFP. While for determining person $^{-1}$ average annual income derived from the selling of a particular NTFP, family ${ }^{-1}$ average annual income derived from the selling of that particular NTFP was divided by average family members involved in day-1 collection of the same NTFP.

\section{Results and Discussion}

\subsection{Seasonal collection of various NTFPS}

Seasonal collection of various NTFPs in the study site is presented in the Table 1 . The findings showed that the respondents were involved in collection of various NTFPs throughout the year. However, most of the NTFPs were collected by the respondents during April-June month. It was observed that during this period, respondents were engaged in collection of 16 different NTFPs viz., mahua, char beej, tendu, tendupatta, jamun, sahad, aam, ber, bel, emli, sahatoot, kathal, sal beej, gond, lakh and bhelwa. While the other NTFPs like putu and chhatani were available in July- 


\begin{tabular}{|c|c|}
\hline $\begin{array}{l}\text { Collection } \\
\text { season }\end{array}$ & Name of collected NTFPs \\
\hline January & Bihi, Harra and Bahera \\
\hline February & Bihi \\
\hline March & Mahua, Sahad, Ber and Emli \\
\hline April & $\begin{array}{l}\text { Mahua, Char beej, Tendupatta, Sahad, Ber, } \\
\text { Emli, Kathal and Sal beej }\end{array}$ \\
\hline May & $\begin{array}{l}\text { Char beej, Tendu, Tendupatta, Sahad, Aam, } \\
\text { Bel, Kathal, Sal beej, Gond, Lakh and Bhelwa }\end{array}$ \\
\hline June & $\begin{array}{l}\text { Tendu, Jamun, Sahad, Aam, Bel, Sahatoot, } \\
\text { Gond, Lakh and Bhelwa }\end{array}$ \\
\hline July & Putu and Chhatani, Jamun and Sahatoot \\
\hline August & Putu and Chhatani \\
\hline September & Putu and Chhatani and Kheksha \\
\hline October & Sitaphal, Kheksha, Aawla and Jimikand \\
\hline November & Sitaphal, Bihi, Aawla and Jimikand \\
\hline December & Bihi, Aawla, Harra and Bahera \\
\hline
\end{tabular}

September, kheksha in September-October, jimikand and sitaphal in October-November, aawla October-December, bihi in November-February and harra and bahera in December-January. So, based on this data it can be inferred that the respondents were engaged in the collection of various NTFPs throughout the year for sustaining their livelihood. Bhattacharya and Hayat (2004) indicated that in Sheopur district of Madhya Pradesh, India, the peak season for NTFPs collection among the respondents was November-February.

3.2. Households involved in collection and part(s) used of various NTFPs

Number of households involved in collection of various NTFPs in the study area is given in Table 2. The findings revealed that all the households (135) were engaged in mahua collection, followed by aam (130), jamun (129), tendupatta (128), sitaphal (125), bihi (123) tendu (112), putu and chhatani or wild edible mushroom (102), ber (76), sal beej (70), char beej (65), harra (53), sahad (31), bel (30), bhelwa (28), emli (27), aawla (25), bahera (20), kathal (17), lakh (14), gond (10), kheksha (07), sahatoot (06) and jimikand (02). The reason for this might be due to the importance of such collected NTFPs in the livelihood of the respondents and the availability of such collected NTFPs in the study area. Singh et al. (2010) identified that in Mangrove forest of Sundarbans, India, nearly $19-25 \%$ of the households were engaged in fishing followed by firewood (15-22\%), both honey and wax collection (15-21\%) and $10-19 \%$ in prawn collection, while almost $7 \%$ and $9 \%$ were engaged in pati grass collection and crab collection, respectively.

Table 2 also described about the part(s) used of various
Table 2: No. of households involved in collection and part(s) used of various NTFPs

\begin{tabular}{|c|c|c|}
\hline Name of particular NTFPs & $\begin{array}{l}\text { No. of } \\
\text { households } \\
\text { involved in } \\
\text { collection }\end{array}$ & $\begin{array}{l}\text { Part(s) } \\
\text { used }\end{array}$ \\
\hline Mahua (Madhuca longifolia) & $\begin{array}{c}135 \\
(100.00 \%)\end{array}$ & Flower \\
\hline Char beej (Buchanania lanzan) & $65(48.15 \%)$ & Seed \\
\hline $\begin{array}{l}\text { Putu and Chhatani (Scleroderma } \\
\text { spp. \& Termitomyces spp.) }\end{array}$ & $\begin{array}{c}102 \\
(75.56 \%)\end{array}$ & $\begin{array}{l}\text { Head } \\
\text { and stalk } \\
\text { of fungi }\end{array}$ \\
\hline Tendu (Diospyros melanoxylon) & $\begin{array}{c}112 \\
(82.96 \%)\end{array}$ & Fruit \\
\hline $\begin{array}{l}\text { Tendupatta (Diospyros melan- } \\
\text { oxylon) }\end{array}$ & $\begin{array}{c}128 \\
(94.81 \%)\end{array}$ & Leaves \\
\hline Sitaphal (Annona squamosa) & $\begin{array}{c}125 \\
(92.59 \%)\end{array}$ & Fruit \\
\hline Jamun (Syzygium cumini) & $\begin{array}{c}129 \\
(95.56 \%)\end{array}$ & Fruit \\
\hline Bihi (Psidium guajava) & $\begin{array}{c}123 \\
(91.11 \%)\end{array}$ & Fruit \\
\hline Sahad (Honey) & $31(22.96 \%)$ & Honey \\
\hline Aam (Mangifera indica) & $\begin{array}{c}130 \\
(96.30 \%)\end{array}$ & Fruit \\
\hline Ber (Ziziphus mauritiana) & $76(56.30 \%)$ & Fruit \\
\hline Bel (Aegle marmelos) & $30(22.22 \%)$ & $\begin{array}{l}\text { Fruit } \\
\text { pulp }\end{array}$ \\
\hline $\begin{array}{l}\text { Kheksha (Momordica subangu- } \\
\text { lata) }\end{array}$ & 07 (05.19\%) & Fruit \\
\hline Emli (Tamarindus indica) & $27(20.00 \%)$ & Fruit \\
\hline Aawla (Phyllanthus emblica) & $25(18.52 \%)$ & Fruit \\
\hline Sahatoot (Morus nigra) & 06 (04.44\%) & Fruit \\
\hline $\begin{array}{l}\text { Kathal (Artocarpus heterophyl- } \\
\text { lus) }\end{array}$ & $17(12.59 \%)$ & Fruit \\
\hline $\begin{array}{l}\text { Jimikand (Amorphophallus paeo- } \\
\text { niifolius) }\end{array}$ & $02(01.48 \%)$ & Tuber \\
\hline Sal beej (Shorea robusta) & $70(51.85 \%)$ & Seed \\
\hline Gond (Gum) & $10(7.41 \%)$ & $\begin{array}{c}\text { Plant } \\
\text { exudates }\end{array}$ \\
\hline Harra (Terminalia chebula) & $53(39.26 \%)$ & Fruit \\
\hline Bahera (Terminalia bellirica) & $20(14.81 \%)$ & Fruit \\
\hline Lakh (Lac) & $14(10.37 \%)$ & Lac \\
\hline $\begin{array}{l}\text { Bhelwa (Semecarpus anacar- } \\
\text { dium) }\end{array}$ & $28(20.74 \%)$ & Fruit \\
\hline
\end{tabular}

${ }^{*}$ Data are based on multiple responses 
collected NTFPs by the respondents. It was observed that in the case of most of the NTFPs, the respondents were utilizing only the fruit part. The names of such NTFPs were as follows: sitaphal, jamun, bihi, aam, ber, kheksha, emli, aawla, sahatoot, kathal, harra, bahera and bhelwa. They had used fruit pulp of beal, seeds of char and sal, tuber in case of jimikand, head and stalk of fungi in case of putu and chhatani and plant exudates of some trees like babool as a gum. They had also used the NTFPs of animal origin like sahad and lakh. While it was also observed that they had used flowers of mahua and fruit and leaves of tendu. Bhattacharya and Hayat (2004) reported that in Sheopur district of Madhya Pradesh, India, the respondents used the flowers and fruit of mahua and aonla, seed of powar and malkangani and they utilized fruit in the case of baheda and marodphali.

\subsection{Collection, consumption and selling pattern of various collected NTFPs among the respondents}

Average collection, consumption and selling pattern of various collected NTFPs by the respondents is given in Table 3.

\subsubsection{Average family members involved in collection of} various NTFPs (day ${ }^{-1}$ )

The average family size in the study area was 5.69 members. With regards to average family members involved in day ${ }^{1}$ collection of particular NTFPs, the data described that maximum average family members i.e., 4.17 members were involving in day $^{-1}$ collection of sahatoot followed by tendupatta (4.11 members), mahua (4.09 members), harra (3.64 members) and for bhelwa and sal beej this figure was 3.54 members, whereas, minimum average family members i.e., 1.35 members were involved in day $^{-1}$ collection of sahad. However, the maximum average family members involved in day ${ }^{-1}$ collection of sahtoot, in respect of number of household engaged in collection of sahtoot was less i.e., only 6 households.

3.3.2. Average number of days devoted in collection of various NTFPs (person ${ }^{-1}$ year $^{-1}$ )

In the context of average number of days devoted in collection (person $^{-1}$ year $^{-1}$ ) the data showed that the respondents were devoting maximum 13.14 days in collection of mahua followed by tendupatta (12.03 days), sal beej (8.03 days), gond (7.43 days), harra (7.08 days), bhelwa (6.86 days) and for aam they devoted 6.75 days. While the least number of days i.e., 2.19 was devoted by the respondents in the collection of kheksha. It might be due to the fact that mahua and tendupatta were available to respondents in plentiful amount in the study area.

\subsubsection{Average collected quantities of various NTFPs}

The data also describes about average quantity collected by person ${ }^{-1}$ day $^{-1}$. With this regard, each respondent collected on an average 30.01 stakes (bundles) of tendupatta day ${ }^{-1}$ (Range 6.25-75.00 stakes), whereas each respondent also collected on an average $8.73 \mathrm{~kg}$ of kathal, $5.97 \mathrm{~kg}$ of bel, $5.00 \mathrm{~kg}$ of emli and $4.17 \mathrm{~kg}$ of ber day ${ }^{-1}$. However, average collection person ${ }^{-1}$ day $^{-1}$ was maximum for kathal, bel and emli but with regard to number of families involved in collection of such NTFPs was less i.e., 17, 30 and 27 households, respectively.

With regard to average quantity collected by family ${ }^{-1}$ year $^{-1}$, the data revealed that each household collected on an average 1483.25 stakes of tendupatta annually. Each household also collected on an average $144.51 \mathrm{~kg}$ of mahua, $79.25 \mathrm{~kg}$ of aam, $55.47 \mathrm{~kg}$ of kathal, $53.75 \mathrm{~kg}$ of sal beej and $50.26 \mathrm{~kg}$ of harra annually. This might be due to the fact that the NTFPs like mahua, tendupatta and aam were available to respondents easily and in abundant quantity. Acharya (2013) found that in Bastar district of Chhattisgarh, India, the respondents collected on an average $272.25 \mathrm{~kg}$ sal beej followed by mahua flower $(211.17 \mathrm{~kg})$ and tamarind $(184.33 \mathrm{~kg})$.

\subsubsection{Average consumed and sold quantities of various NTFPs}

In the case of average quantity consumed ( $\mathrm{kg} \mathrm{family}^{-1}$ year $^{-1}$ ) of various NTFPs, it was found that each family consumed in a year maximum average quantity of aam (34.21 kg) followed by mahua $(25.79 \mathrm{~kg})$, kathal $(22.06 \mathrm{~kg})$, sitaphal $(21.34 \mathrm{~kg})$ and ber $(20.16 \mathrm{~kg})$ from the average collected quantity of each NTFP in a year. Whereas, with respect to average quantity sold ( $\mathrm{kg} \mathrm{family}^{-1}$ year $^{-1}$ ), It was observed that they had sold all the average collected quantity (i.e. 100\%) of tendupatta and lakh in a year.

Figure 1 illustrated about the annual consumption and selling pattern of total collected quantities of various NTFPs among the respondents. It could be inferred from Figure 1 that the sample households consumed $70.18 \%$ of total collected quantity of kheksha in a year followed by putu and chhatani (69.30\%), tendu (62.49\%), bel (62.33\%), and ber $(57.86 \%)$. It might be due to the fact that maximum proportion of total collected quantities of such NTFPs were utilized by the respondents in their food. So, it could be said that, on the basis of such data, the consumption of such NTFPs contributed in the nutritional requirement, food security and ultimately in the sustainable livelihood of the respondents. Hence, the respondents were collecting maximum quantities of those NTFPs which were more important for their sustainable

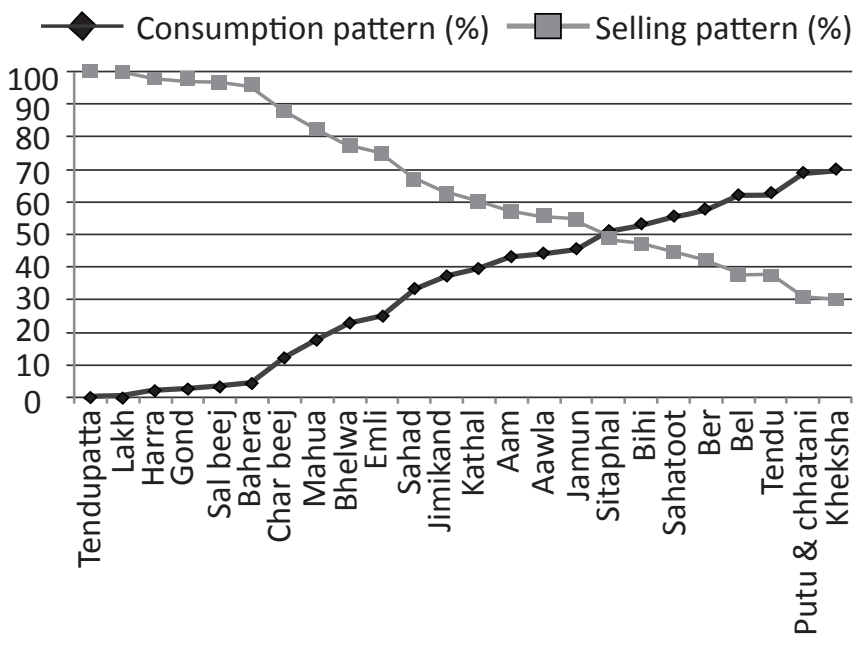

Figure 1: Annual consumption and selling pattern of total collected quantities of various NTFPs among the respondents 
livelihood. However, kheksha had maximum consumption by the respondents but the number of families involved in collection of kheksha was less (i.e., 7 families) than the other NTFPs.

Figure 1 also revealed that the sample households were selling $100 \%$ of total collected quantities of tendupatta and lakh in a year. It might be due to the non-edible nature of such NTFPs. The sample households had also sold the other NTFPs like harra (97.94\%), gond (97.54\%), sal beej (96.61\%) and bahera $(95.88 \%)$ in a year. So the respondents had sold those quantities of NTFPs that remained with them after meeting their family and other requirements. Acharya (2013) indicated that in Bastar district of Chhattisgarh, India, the respondents consumed $40.44 \%$ of total collected quantity of mushroom followed by honey (22.94\%) and chironjee (19.56\%), whereas they had sold $100 \%$ of total collected quantities of sal seed, tendu leaves, harra, baheda, karanj seed and kalmegh.

\subsubsection{Average price of various NTFPs}

Average price $\left(\mathrm{kg}^{-1}\right)$ of each collected NTFP is given in Table 3 and it showed that putu and chhatani fetches maximum price i.e., ₹ 196.67 followed by sahad (₹ 180.00), lakh (₹

\begin{tabular}{|c|c|c|c|c|c|c|c|c|c|c|c|}
\hline \multirow[t]{2}{*}{$\begin{array}{l}\text { Name of } \\
\text { NTFPs }\end{array}$} & \multirow[t]{2}{*}{$\mathrm{NHI}$} & \multirow[t]{2}{*}{ AFM } & \multirow[t]{2}{*}{ AND } & \multicolumn{2}{|c|}{$\begin{array}{l}\text { Quantity collected } \\
\left(\text { kg day }^{-1} \text { person }^{-1}\right)\end{array}$} & \multirow[t]{2}{*}{$A Q C$} & \multirow[t]{2}{*}{$A Q$} & \multirow[t]{2}{*}{ AQS } & \multirow{2}{*}{$\begin{array}{c}\text { Average } \\
\text { price } \\
\left(\mathrm{kg}^{-1}\right)\end{array}$} & \multicolumn{2}{|c|}{$\begin{array}{c}\text { Average } \\
\text { annual income (₹) }\end{array}$} \\
\hline & & & & Range & Average & & & & & Family $^{-1}$ & Person $^{-1}$ \\
\hline Mahua & 135 & 4.09 & 13.14 & $0.50-7.60$ & 2.69 & 144.51 & 25.79 & 118.71 & 18.33 & 2176.04 & 532.18 \\
\hline Char beej & 65 & 3.12 & 5.05 & $0.25-3.00$ & 1.31 & 20.59 & 2.50 & 18.08 & 106.67 & 1928.68 & 617.56 \\
\hline $\begin{array}{l}\text { Putu \& } \\
\text { chhatani }\end{array}$ & 102 & 3.23 & 3.84 & $0.06-0.87$ & 0.32 & 4.00 & 2.77 & 1.23 & 196.67 & 241.56 & 74.89 \\
\hline Tendu & 112 & 1.96 & 3.70 & $0.50-6.00$ & 4.05 & 29.40 & 18.37 & 11.03 & 16.67 & 183.82 & 93.78 \\
\hline Tendupatta* & 128 & 4.11 & 12.03 & $6.25-75.00^{* 2}$ & 30.01 & 1483.25 & 0.00 & 1483.25 & $1.20^{* 3}$ & 1779.90 & 433.13 \\
\hline Sitaphal & 125 & 2.34 & 4.54 & $0.50-5.00$ & 3.93 & 41.62 & 21.34 & 20.28 & 19.44 & 394.17 & 168.74 \\
\hline Jamun & 129 & 2.37 & 4.71 & $0.67-5.00$ & 3.89 & 43.39 & 19.76 & 23.63 & 15.44 & 364.81 & 153.79 \\
\hline Bihi & 123 & 2.20 & 4.43 & $0.50-5.00$ & 3.81 & 36.99 & 19.65 & 17.33 & 20.22 & 350.48 & 159.66 \\
\hline Sahad & 31 & 1.35 & 3.35 & $0.50-2.50$ & 3.32 & 15.10 & 5.02 & 10.08 & 180.00 & 1814.52 & 1339.29 \\
\hline Aam & 130 & 2.84 & 6.75 & $1.00-6.67$ & 4.14 & 79.25 & 34.21 & 45.04 & 32.78 & 1476.49 & 520.17 \\
\hline Ber & 76 & 2.16 & 3.87 & $0.83-5.50$ & 4.17 & 34.85 & 20.16 & 14.68 & 10.44 & 153.30 & 71.04 \\
\hline Bel & 30 & 1.40 & 2.70 & $0.50-5.00$ & 5.97 & 22.57 & 14.07 & 8.50 & 5.33 & 45.31 & 32.36 \\
\hline Kheksha & 7 & 2.14 & 2.19 & $0.10-3.00$ & 3.32 & 15.57 & 10.93 & 4.64 & 17.67 & 82.04 & 38.29 \\
\hline Emli & 27 & 1.81 & 2.67 & $0.17-7.00$ & 5.00 & 24.19 & 6.09 & 18.09 & 31.78 & 574.98 & 316.83 \\
\hline Aawla & 25 & 2.80 & 4.60 & $0.50-3.00$ & 1.61 & 20.80 & 9.20 & 11.60 & 43.04 & 499.26 & 178.31 \\
\hline Sahatoot & 6 & 4.17 & 4.78 & $0.67-5.00$ & 1.68 & 33.50 & 18.58 & 14.92 & 21.67 & 323.24 & 77.58 \\
\hline Kathal & 17 & 1.71 & 3.73 & $0.50-10.00$ & 8.73 & 55.47 & 22.06 & 33.41 & 11.33 & 378.56 & 221.91 \\
\hline Jimikand & 2 & 1.50 & 3.00 & $1.00-2.00$ & 2.67 & 12.00 & 4.50 & 7.50 & 28.33 & 212.48 & 141.65 \\
\hline Sal beej ${ }^{*}$ & 70 & 3.54 & 8.03 & $0.50-5.00$ & 1.89 & 53.75 & 1.82 & 51.93 & 10.00 & 519.29 & 146.57 \\
\hline Gond & 10 & 2.60 & 7.43 & $0.58-1.25$ & 1.42 & 27.45 & 0.68 & 26.78 & 70.55 & 1888.98 & 726.53 \\
\hline Harra & 53 & 3.64 & 7.08 & $0.37-5.00$ & 1.95 & 50.26 & 1.04 & 49.23 & 12.67 & 623.70 & 171.27 \\
\hline Bahera & 20 & 3.05 & 5.87 & $0.70-5.00$ & 1.93 & 34.58 & 1.43 & 33.15 & 9.11 & 302.00 & 99.02 \\
\hline Lakh & 14 & 2.79 & 4.60 & $0.15-0.25$ & 0.31 & 4.00 & 0.00 & 4.00 & 141.11 & 564.94 & 202.80 \\
\hline Bhelwa & 28 & 3.54 & 6.86 & $0.62-2.50$ & 1.58 & 38.32 & 8.68 & 29.64 & 17.44 & 516.97 & 146.21 \\
\hline
\end{tabular}

NHI: No. of households involved in collection; AFM: Average family members involved in collection (day ${ }^{-1}$ ); AND: Average number of days devoted in collection (person ${ }^{-1}$ year ${ }^{-1}$ ); AQC: Average quantity collected ( $\mathrm{kg}$ family $^{-1}$ year $\left.{ }^{-1}\right)$; AQ: Average quantity consumed ( $\mathrm{kg}$ family ${ }^{-1}$ year $\left.{ }^{-1}\right)$; AQS: Average quantity sold $\left(\mathrm{kg}\right.$ family ${ }^{-1}$ year $\left.{ }^{-1}\right)$; ${ }^{*}$ Price fixed by Government of Chhattisgarh; ${ }^{{ }^{2}}$ Quantity collected in number of stakes (1 stake $=52$ leaves); ${ }^{* 3}$ Price in $₹$ stake ${ }^{-1}$; Note: All the data were related to only those households who were actually involved in collection of particular NTFPs 
141.00) and char beej (₹ 106.67). This might be because of the lesser natural production of such NTFPs. The lesser natural production of such NTFPs further resulted in their lesser availability in the market. This lesser market availability of such NTFPs ultimately resulted in their more market prices, while government purchased tendupatta ( $₹ 1.2$ stake $^{-1}$ ) and sal beej (₹ $10 \mathrm{~kg}^{-1}$ ) on msp. Ghosal (2011) identified that in Purulia, Bankura and West Midnapur districts of West Bengal, India, the price of sal leaf was maximum ( $₹ 70$ for 1000 plates) among all collected NTFPs while the prices of other NTFPs like kend leaf was ₹ 20 bundle $^{-1}$ and ₹ $10 \mathrm{~kg}^{-1}$ for kend fruit, jam fruit and mushroom.

\subsubsection{Average annual income obtained from various NTFPS}

With regard to average annual income family ${ }^{-1}$, the data described that maximum annual earnings came from mahua i.e., ₹ 2176.04 . It might be because of the fact that most of the respondents sold out maximum proportion of total collected quantity of mahua than other NTFPs. While next to mahua, maximum annual earning family ${ }^{-1}$ comes from char beej ( $₹$ 1928.68) followed by gond (₹ 1888.98), sahad (₹ 1814.52) and tendupatta ( $₹$ 1779.90). The minimum average annual earnings came from selling of bel i.e., ₹ 45.31. Singh et al. (2010) concluded that in Mangrove Forest of Sundarban, India, the maximum average annual income generated among NTFPs dependant households through the collection of fishes (₹ 64885) followed by prawn seed (₹ 56040), crab (₹ 6443), honey (₹ 3886) and wax (₹ 680). While, Bhattacharya and Hayat (2004) reported that in Sheopur district of Madhya Pradesh, India, the maximum annual household income generated among the respondents through the collection of salai gum ( $₹ 4500$ ) followed by aonla ( $₹ 2200$ ) and ₹ 1200 earned from the collection of both satavar and tendu patta.

Finally, the data on average annual income person ${ }^{-1}$ revealed that maximum annual earnings came from sahad ( $₹$ 1339.29) followed by gond (₹ 726.53), char beej ( $₹$ 617.56), mahua ( $₹$ 532.18) and tendupatta (₹ 433.13), while it was least in the case of bel (₹ 32.36). However, annual income family ${ }^{-1}$ and person ${ }^{-1}$ obtained from gond and sahad were maximum, but the number of families involved in collection was less (i.e., 10 and 31 families, respectively) than the other NTFPs collection.

\subsection{Factors affecting the availability of various NTFPs in the} study area

The respondents were enquired regarding their perception about factors affecting the availability of various NTFPs in the study area. The responses by them are presented in Table 4 . The data revealed that the majority of respondents (94.81\%) perceived bad weather (heavy and continuous rainfall and blockage of road by the over flow of the rain water, etc.) as a main factor affecting their availability. It might be because of the fact that bad weather affected the natural production of such NTFPs. This ultimately affected their natural availability for collection by the tribes.

While the other factors perceived by them were as follows:
Table 4: Factors affecting the availability of various NTFPs

\begin{tabular}{lcc}
\hline Particular & Frequency & $\%$ \\
\hline Bad weather (Heavy and continu- & 128 & 94.81 \\
$\begin{array}{l}\text { ous rainfall and blockage of road by } \\
\text { the over flow of the rain water etc) }\end{array}$ & & \\
Attack of wild animals & 117 & 86.67 \\
Forest rule and regulations & 74 & 54.81 \\
Deforestation & 116 & 85.93 \\
Over collection by outsiders & 103 & 76.30 \\
Damage of plant during collection & 82 & 60.74 \\
Climate change (Unseasonal rainfall, & 44 & 32.59 \\
raise in temperature etc) & & \\
Natural calamities (Drought, forest & 38 & 28.15 \\
fire, storm etc) & & \\
Ownership of trees & 53 & 39.26 \\
Small family size & 63 & 46.67 \\
\hline
\end{tabular}

"Data are based on multiple responses

attack by wild animals ( $86.67 \%)$, deforestation ( $85.93 \%)$, over collection by outsiders $(76.30 \%)$, damage of plant during collection (60.74\%), forest rule and regulations (54.81\%), small family size (46.67\%), ownership of trees (39.26\%), climate change (unseasonal rainfall, raise in temperature) $(32.59 \%)$ and natural calamities (drought, forest fire, storm, etc.) $(28.15 \%)$. Acharya (2013) portrayed that deforestation was the main constraint faced by $21.67 \%$ of the sampled NTFPs collectors followed by forest fire $(15.00 \%)$ and competition amongst collectors $(5.00 \%)$.

\section{Conclusion}

The respondents were involved in collection of those NTFPs which had importance in their diet and/or which had economic value in market. Collection and marketing of such NTFPs plays an important role in livelihoods security of the respondents. So, there is a need to develop some policies that should promote long term sustainable use of such available NTFPs resources on one hand and also prevent it from their depletion and unsustainable utilization on the other hand.

\section{References}

Acharya, G.K., 2013. An economic analysis of collection, primary processing and marketing of Non-timber forest products in Bastar district of Chhattisgarh. M.Sc. (Agriculture) Thesis, IGKV, Raipur (C.G.).

Ambrose-Oji, B., 2003. The contribution of NTFPs to the livelihoods of the forest poor: evidence from the tropical forest zone of south-west Cameron. International Forestry Review 5(2), 106-117.

Anonymous, 2013. Statewise estimates of value of output from agriculture and allied activities. Central statistics office, 
ministry of statistics and programme implementation, Government of India, New Delhi-110001. Available from: http://sdp.gov.in/writereaddata/Statewise_Estimates_ of_Value_of_Output_from_Agri_and_allied_2013.pdf.

Appasamy, P.P., 1993. Role non timber forest products in a subsistence economy: the case of a joint forestry project in India. Economic Botany 47(3), 258-267.

Bhattacharya, P., Hayat, S.F., 2004. Sustainable NTFP management for rural development: a case from Madhya Pradesh, India. International Forestry Review 6(2), 161-168.

Chamberlain, J.L., Bush, R., Hammett, A.L., 1998. Non-timber forest products: The other forest products. Forest Products Journal 48(10), 2-12.

Chopra, K., 1993. The value of non-timber forest products: an estimation for tropical deciduous forests in India. Economic Botany 47(3), 251-257.

Cottray, O., Miles, L., Newton, A., 2003. African forests and livelihoods. UNEP-WCMC, Cambridge, UK.

FAO., 2008. An Information bulletin on non wood forest products. Non-Wood News. FAO, Rome, Italy, 17, 12-21.

Ghosal, S., 2011. Importance of non-timber forest products in native household economy. Journal of Geography and Regional Planning 4(3), 159-168.

Hegde, R., Suryaprakash, S., Achoth, L., Bawa, K.S., 1996. Extraction of non-timber forest products in the forests of Biligiri Rangan Hills, India: 1. Contribution to rural income. Economic Botany 50(3) 243-251.

Mitchell, C.P., Corbridge, S.E., Jewit, S. L., Mahapatra, A.K., Kumar, S., 2003. Non timber forest products: availability, production, consumption, management and marketing in eastern India, on line cited on $28^{\text {th }}$ April 2005. Available from https://assets.publishing.service.gov. uk/media/57a08ce8ed915d3cfd0016d4/R6916FTR.pdf.

Muthyalu, M., 2008. Collection and marketing practices of non-timber forest produce (NTFP) -an empirical analysis. Blue Ocean Research Journals 2(1), 121-130.

Peters, C.M., Gentry, A.H., Mendelsohn, R.O., 1989. Valuation of an amazonian rainforest. Nature 339(29), 655-656.

Rout, S.D., Panda, S.K., Mishra, N., Panda, T., 2010. Role of tribals in collection of commercial non-timber forest products in Mayurbhanj district, Orissa. Studies of Tribes and Tribals 8(1), 21-25.

Saha, D., Sundriyal, R.C., 2013. Perspectives of tribal communities on NTFP resource use in a global hotspot: implications for adaptive management. Journal of Natural Sciences Research 3(4), 125-169.

Sarmah, R., Arunachalam, A., 2011. Contribution of nontimber forest products (NTFPs) to livelihood economy of the people living in forest fringes in changlang district of Arunachal Pradesh, India. Indian Journal of Fundamental and Applied Life Sciences 1(2) 157-169.

Sarmah, R., Arunachalam, A., Majumder, M., Melkania, U., Adhikari, D., 2006. Ethno-medico-botany of chakmas in Arunachal Pradesh, India. The Indian Forester, 132(4), 474-484.

Sawhney, P., Engel, S., 2003. Importance of Non-timber Forest Produce for Subsistence and Income Generation in the Life of Local People. Case of Bandhavgarh National Park, India. Centre for Development Research (ZEF), WalterFlex-Str. 3, 53113 Bonn.

Shiva, M.P., 1993. Solutions to overcome impediments in forests development through MFP based management. In: International seminar on MFP in Forestry, $17-18^{\text {th }}$ April, Dehradun, India.

Singh, A., Bhattacharya, P., Vyas, P., Roy, S., 2010. Contribution of NTFPs in the livelihood of mangrove forest dwellers of Sundarban. Journal of Human Ecology 29(3), 191-200.

Vedeld, P., Angelsen, A., Bojo, J., Sjaastad, E., Berg, G.K., 2007. Forest environmental incomes and the rural poor. Forest Policy and Economics 9(7), 869-879.

Wilkinson, M.K., Elivitch, R.C., 2000. Non-Timber Forest Products for Pacific Islands: An Introductory Guide for Producers. Agroforestry Guides for pacific Islands, Permanent Agriculture Resources, Holualoa, Hawaii, USA. 